\title{
Effects of Florida Red Tides on histone variant expression and DNA methylation in the Eastern oyster Crassostrea virginica
}

\author{
Rodrigo Gonzalez-Romero ${ }^{\mathrm{a}, 1}$, Victoria Suarez-Ulloa ${ }^{\mathrm{a}, 1}$, Javier Rodriguez-Casariego $^{\mathrm{a}, \mathrm{b}}$, \\ Daniel Garcia-Souto ${ }^{\mathrm{c}}$, Gabriel Diaz $^{\mathrm{a}}$, Abraham Smith ${ }^{\mathrm{b}}$, Juan Jose Pasantes ${ }^{\mathrm{c}}$, Gary Rand ${ }^{\mathrm{b}}$, \\ Jose M. Eirin-Lopez ${ }^{\text {a,* }}$ \\ a Environmental Epigenetics Group, Department of Biological Sciences, Florida International University, North Miami, FL 33181, USA \\ ${ }^{\mathrm{b}}$ Ecotoxicology and Risk Assessment Laboratory, Southeast Environmental Research Center, Florida International University, North Miami, FL 33181, USA \\ ${ }^{c}$ Departamento de Bioquimica, Xenetica e Inmunoloxia, Universidade de Vigo, E-36310 Vigo, Spain
}

\section{A R T I C L E I N F O}

\section{Article history:}

Received 2 December 2016

Received in revised form 2 March 2017

Accepted 3 March 2017

Available online 7 March 2017

\section{Keywords:}

Epigenetics

Environment

Harmful algal blooms

Brevetoxins

Oysters

Histone variants

DNA methylation

\begin{abstract}
A B S T R A C T
Massive algal proliferations known as Harmful Algal Blooms (HABs) represent one of the most important threats to coastal areas. Among them, the so-called Florida Red Tides (FRTs, caused by blooms of the dinoflagellate Karenia brevis and associated brevetoxins) are particularly detrimental in the southeastern U.S., causing high mortality rates and annual losses in excess of $\$ 40$ million. The ability of marine organisms to cope with environmental stressors (including those produced during HABs) is influenced by genetic and epigenetic mechanisms, the latter resulting in phenotypic changes caused by heritable modifications in gene expression, without involving changes in the genetic (DNA) sequence. Yet, studies examining cause-effect relationships between environmental stressors, specific epigenetic mechanisms and subsequent responses are still lacking. The present work contributes to increase this knowledge by investigating the effects of Florida Red Tides on two types of mechanisms participating in the epigenetic memory of Eastern oysters: histone variants and DNA methylation. For that purpose, a HAB simulation was conducted in laboratory conditions, exposing oysters to increasing concentrations of $K$. brevis. The obtained results revealed, for the first time, the existence of H2A.X, H2A.Z and macroH2A genes in this organism, encoding histone variants potentially involved in the maintenance of genome integrity during responses to the genotoxic effect of brevetoxins. Additionally, an increase in H2A.X phosphorylation ( $\gamma$ H2A.X, a marker of DNA damage) and a decrease in global DNA methylation were observed as the HAB simulation progressed. Overall, the present work provides a basis to better understand how epigenetic mechanisms participate in responses to environmental stress in marine invertebrates, opening new avenues to incorporate environmental epigenetics approaches into management and conservation programs.
\end{abstract}

(c) 2017 Elsevier B.V. All rights reserved.

\section{Introduction}

The impacts of global change on marine ecosystems are dramatic, as evidenced by growing pollution and acidification, sea

Abbreviations: AMOVA, analysis of molecular variance; HABs, harmful algal blooms; FRT, Florida Red Tide; MSAP, methylation sensitive amplified polymorphism; NTC, no template control; NRTC, non-reverse transcription control; NSP, neurotoxic shellfish poisoning; PCA, principal component analysis; PTMs, posttranslational modifications; SDS-PAGE, sodium dodecyl-sulfate polyacrylamide gel electrophoresis.

* Corresponding author.

E-mail address: jeirinlo@fiu.edu (J.M. Eirin-Lopez).

1 These authors have contributed equally to this work.

http://dx.doi.org/10.1016/j.aquatox.2017.03.006

0166-445X/C 2017 Elsevier B.V. All rights reserved. level rise, and changes in ocean temperature and currents (Curry and Mauritzen, 2005). Among them, the increase in the frequency and toxicity of episodes of massive algal proliferations known as Harmful Algal Blooms (HABs) represents one of the most important threats to fisheries, aquaculture-based industries, and human populations in coastal areas (Mat et al., 2013; Cook et al., 2015). During HABs, large amounts of potentially harmful biotoxins are produced and recruited into the human food chain through their accumulation by edible marine organisms (Cardozo et al., 2007; Plakas et al., 2008). These biotoxins, among other relevant effects, have the ability to cause DNA damage, both in marine organisms and human consumers of contaminated shellfish (Valdiglesias et al., 2013; Prego-Faraldo et al., 2015; Prego-Faraldo et al., 2016). 

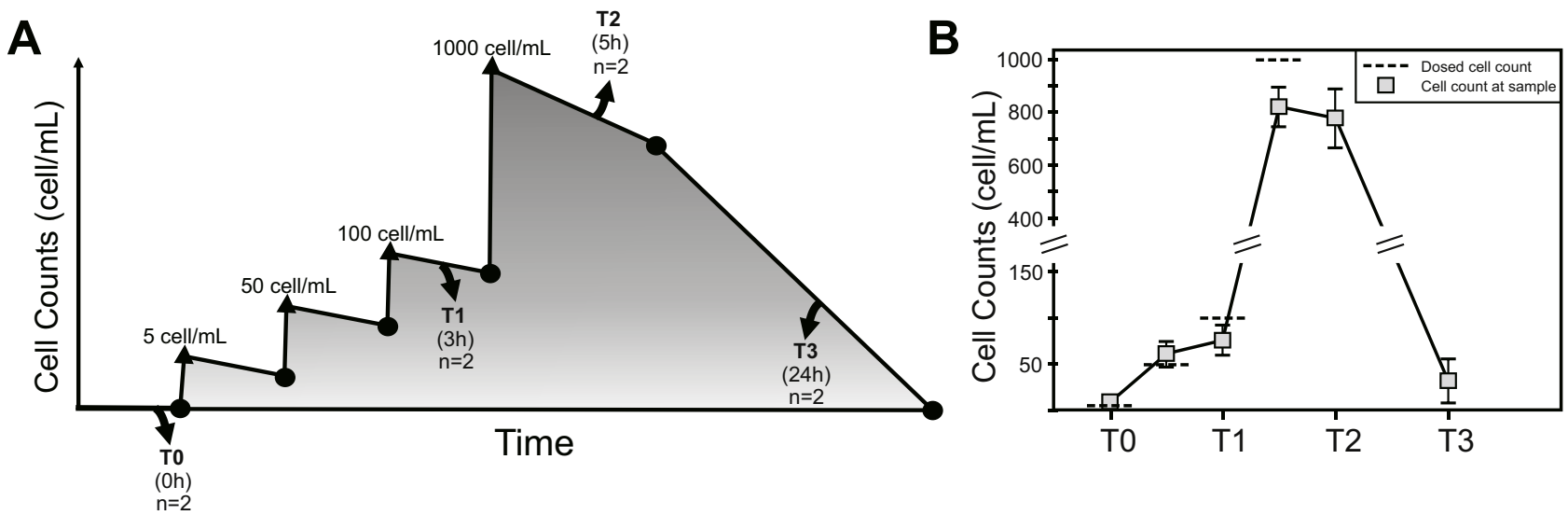

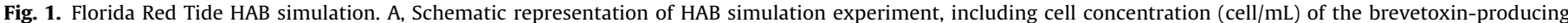

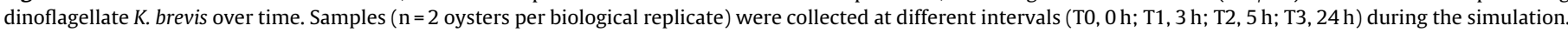

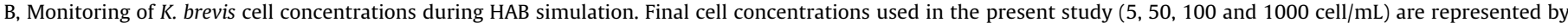

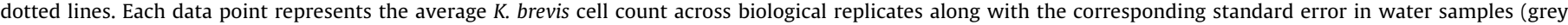
squares), measured after application of $K$. brevis cell cultures to experimental tanks.

The southeastern U.S. is particularly affected by HABs (Flewelling et al., 2005), notably by the so-called Florida Red Tides [FRTs, blooms of the dinoflagellate Karenia brevis (Davis, 1948; Brand and Compton, 2007)] and associated brevetoxins (PbTx). FRTs are responsible for high mortality rates of marine invertebrates, fishes and marine mammals (Brand et al., 2012), causing annual losses in excess of $\$ 40$ million (Twiner et al., 2007). The consumption of brevetoxin-laden shellfish causes Neurotoxic Shellfish Poisoning (NSP) syndrome (McFarren et al., 1965), and exposure to aerosolized brevetoxins is responsible for respiratory distress (Abraham et al., 2005) and severe allergic reactions in humans (Fleming et al., 2007). Furthermore, brevetoxins convey critical disruptive effects at the most fundamental level, as they can induce DNA damage and apoptosis (Radwan and Ramsdell, 2008; Murrell and Gibson, 2009, 2011). Still, while the harmful effects of brevetoxins are well documented, the role these biotoxins play in $K$. brevis is still uncertain (Sunda et al., 2013; Errera et al., 2014).

Coastal areas bear the brunt of HABs, impacting marine communities and commercial resources, especially the aquaculture industry. Consequently, bivalve molluscs are generally used as sentinel organisms to study HAB pollution (Collin et al., 2010; Campos et al., 2012; Fernandez-Tajes et al., 2012; Luchmann et al., 2012; Milan et al., 2013; Suarez-Ulloa et al., 2013; Prego-Faraldo et al., 2015, 2016). Eastern oysters (Crassostrea virginica) are particularly relevant due to their abundance, economic importance and major role in the function of estuary ecosystems in areas affected by FRTs (Dame, 1972). During these episodes Eastern oysters rapidly accumulate brevetoxins (Plakas et al., 2002), causing mortality and interfering with larval development (Leverone et al., 2006; Rolton et al., 2014). At the subcellular level, the exposure to high brevetoxin concentrations was previously linked to the activation of specific molecular mechanisms involved in defense, detoxification and stress response in oysters (Mello et al., 2012), including advanced apoptosis and apoptosis-regulating systems (Zhang et al., 2014). Similarly, the presence of oxidative stress was described in other marine organisms including corals, turtles and manatees, as a consequence of exposure to K. brevis during FRTs (Ross et al., 2010; Perrault et al., 2014; Walsh et al., 2015).

Traditionally, the ability of organisms to cope with adverse environmental conditions such as those imposed by HABs was attributed to specifically adapted genotypes (Hoffmann and Willi, 2008). However, we now know that responses to environmental changes are largely dependent on epigenetic regulatory mechanisms, in other words, heritable changes in gene expression resulting from modifications in chromatin structure, without involving changes in the genetic information stored in DNA (Allis et al., 2007; Feil and Fraga, 2012). The study of the epigenetic mechanisms mediating exposure-response relationships constitutes the basis for environmental epigenetic analyses (Baccarelli and Bollati, 2009; Bollati and Baccarelli, 2010), providing information about how different environmental factors influence phenotypic variation (Cortessis et al., 2012; Suarez-Ulloa et al., 2015; Etchegaray and Mostoslavsky, 2016). Chromatin, the association between DNA and chromosomal proteins, provides a framework for the study of epigenetic modifications, including DNA methylation, histone variants [a set of minority histone proteins encompassing specialized functions in chromatin metabolism (Henikoff and Smith, 2015)] and their post-translational modifications (PTMs), as well as non-coding RNAs, among others (Kouzarides, 2007; Ptashne, 2007; Arya et al., 2010; Talbert and Henikoff, 2010; Mercer and Mattick, 2013). These modifications define specific epigenomic states throughout the genome that are susceptible of being transmitted trans-generationally (both mitotically and meiotically), setting the basis for short-term acclimatization and long-term adaptation (Migicovsky and Kovalchuk, 2011; Fernandez et al., 2014).

Among marine invertebrates, bivalve molluscs constitute emerging models in environmental epigenetics, as illustrated by recent studies examining the role of DNA methylation in the Pacific oyster (Gavery and Roberts, 2010, 2013, 2014; Diaz-Freije et al., 2014; Olson and Roberts, 2014) and the characterization of chromatin structure and histone variants in mussels (González-Romero et al., 2012; Rivera-Casas et al., 2016a,b). Yet, studies examining cause-effect relationships between environmental stressors, specific epigenetic mechanisms and subsequent responses in marine invertebrates are still lacking. That is primarily due to the absence of genomic information for many environmentally and ecologically relevant organisms, along with a scarce knowledge about their chromatin structure and dynamics (Arenas-Mena et al., 2007; Schulmeister et al., 2007; Suarez-Ulloa et al., 2015). The present work fills that gap by studying the role of two different epigenetic mechanisms during Eastern oyster responses to FRTs. First, given the genotoxic effect of brevetoxins produced during FRTs (Radwan and Ramsdell, 2008; Murrell and Gibson, 2009, 2011), this study targets a group of three histone variants known to be involved in the maintenance of genome integrity, namely H2A.X, H2A.Z, and macroH2A (Li et al., 2005; Ivashkevich et al., 2012; Shi and Oberdoerffer, 2012; Papamichos-Chronakis and Peterson, 
2013; Khurana et al., 2014). Although the presence of these variants has not been yet described in oysters, our previous results on other mollusc species support that notion (González-Romero et al., 2012; Rivera-Casas et al., 2016a,b). Second, the study of environmental epigenetic responses is completed by the analysis of genome-wide DNA methylation patterns during FRTs. The obtained results are consistent with a role for histone H2A.X phosphorylation ( $\gamma \mathrm{H} 2 \mathrm{~A} . \mathrm{X}$ ) and DNA methylation during exposure to the brevetoxin-producing dinoflagellate K. brevis.

\section{Materials and methods}

\subsection{Specimen collection and laboratory acclimatization}

Eastern oyster specimens were collected at Rookery Bay National Estuarine Research Reserve, Naples FL (coordinates 26.050026, -81.700774). Collected organisms were transported to the laboratory and acclimatized to controlled conditions of temperature $\left(25 \pm 2^{\circ} \mathrm{C}\right.$ ), aeration (dissolved oxygen $>6 \mathrm{mg} / \mathrm{L}$ ), salinity $(30 \pm 2 \mathrm{ppt})$, light cycle and substrate in a recirculating seawater system for 5 weeks. During this period, oyster specimens were fed twice a day using a commercial mix of marine microalgae $(1 \mathrm{~mL}$ per 30L tank) including Isochrysis sp., Pavlova sp., Tetraselmis sp., Chaetoceros calcitrans, Thalassiosira weissflogii and T. pseudonana (Shellfish Diet 1800, REED MARICULTURE). The concentrated diet was diluted with filtered seawater $(1: 10)$ to ensure separation of microalgae cells.

\subsection{Experimental $H A B$ simulation}

The present work simulated the toxic effect resulting from the exposure of Eastern oysters to an incoming patch of $K$. brevis HAB that disappears within $24 \mathrm{~h}$ (Stumpf et al., 2003). HAB simulations were carried out in the laboratory using an exponential culture of the brevetoxin-producing dinoflagellate $K$. brevis (approx. 45,000 cells/mL, courtesy of Dr. K. Rein, Florida International University). Toxin content in microalgae cultures was estimated using LC-MS as 5.0-6.8 pg/cell (Sun et al., 2016). Given that the present work aimed to simulate a natural FRT episode, $K$. brevis exposures were chosen over exposures to purified brevetoxins. The latter have major limitations for that purpose, including the existence of several brevetoxins subtypes (not all can be purified) and their high hydrophobicity, hampering homogeneous solution in seawater. Two groups of oysters (control and treated) were defined in the simulation, each consisting of 3 experimental units (biological replicates) with 20 individuals/unit (80 individuals per group). Each experimental unit consisted of a static $20 \mathrm{~L}$ tank where oysters were fed and acclimatized to controlled conditions for $24 \mathrm{~h}$ prior to exposure to $K$. brevis. Treated experimental units were subsequently exposed to increasing concentrations of $K$. brevis, starting at $5 \mathrm{cell} / \mathrm{mL}$ and reaching $1000 \mathrm{cell} / \mathrm{mL}$ after $5 \mathrm{~h}$ exposure (Fig. $1 \mathrm{~A}$ ). These conditions mirror $K$. brevis levels during a typical mediumhigh intensity FRT episode (Stumpf et al., 2003).

Specimens were initially fed with lower microalgae volumes $(0.1 \mathrm{~mL}$ per $20 \mathrm{~L}$ tank) in order to promote feeding behavior. Effects of high algal densities were controlled in tanks exposed to $K$. brevis by monitoring water quality (salinity, $\mathrm{pH}$, dissolved oxygen, and conductivity) and oyster feeding behavior (production of feces). These parameters remained constant within optimal levels throughout the experiment, discarding significant effects of increased algal levels in exposed individuals. Cell concentrations of $K$. brevis were quantified hourly using a Multisizer 4 Coulter Counter instrument (BECKMAN-COULTER). Dosage was adjusted to maintain homogeneous microalgae concentrations across replicates (Fig. 1B). Specimens ( $\mathrm{n}=2$ oysters per biological replicate)
Table 1

qPCR primers used in gene expression analyses, specifically designed to amplify histone variant genes and reference genes in Eastern oyster.

\begin{tabular}{lll}
\hline Gene & Primer Name & Sequence $\left(5^{\prime} \rightarrow 3^{\prime}\right)$ \\
\hline H2A.X & Cv-H2A.X-Fw & AGTTACCATTGCCCAAGGAGG \\
& Cv-H2A.X-Rv & AAAATTCCTGGACTGTGACGA \\
H2A.Z & Cv-H2A.Z-Fw & CGCCATCAGAGGAGACGAAG \\
& Cv-H2A.Z-Rv & AGCTGTTTCTGTGTGCCT \\
MacroH2A & Cv-mH2A-Fw & TCATTTCCGTATCGGAGCGG \\
& Cv-mH2A-Rv & CTCTTGCAGCATTTCCAGCC \\
GAPDH & Cv-GAPDH-Fw & GACAACAGTCCACGCCTACA \\
& Cv-GAPDH-Rv & GGATGACCTTACCCACTGCC \\
RPL13 & Cv-RPL13-Fw & CCGGGCTCCCAGTAAAATGT \\
& Cv-RPL13-Rv & TGTCGTATGGGGGAGGGATT \\
\hline
\end{tabular}

were collected at 4 different time points: T0, before exposure begins; T1, after $3 \mathrm{~h}$ exposure; T2, after $5 \mathrm{~h}$ exposure; T3, after $24 \mathrm{~h}$ exposure. Upon sampling, oysters were shucked, and gills were dissected and immediately flash-frozen in liquid nitrogen. The choice of gill tissue as model system in the present work was motivated by previous reports indicating that gills are the part of the organism first contacted by biotoxins during HABs, experiencing substantial DNA damage (Prego-Faraldo et al., 2015, 2016).

\subsection{Gene expression analysis}

Total RNA was extracted from gill cells using Ribozol Reagent (AMRESCO) and digested with PerfeCTa DNase I (QUANTA BIOSCIENCES) to eliminate residual genomic DNA. cDNA was synthesized using qScript cDNA Supermix (QUANTA BIOSCIENCES). Expression analyses were performed by means of quantitative PCR (qPCR) experiments. Accordingly, specific primers for Eastern oyster H2A.X, H2A.Z, and macroH2A histone genes were designed based on sequences retrieved from GenBank (Table 1) using PrimerBLAST software (Ye et al., 2012). Primers were also generated for GAPDH and RPL13, used as reference genes for normalization purposes. Primer efficiency was calculated based on the slope of calibration curves constructed using ten-fold dilution steps, according to the formula $E=10^{-1 / \text { slope }}$.

Gene expression profiles were examined in gills from Eastern oyster by measuring SYBR green incorporation, using FastStart Essential DNA Green Master (ROCHE) in a LightCycler 96 System (ROCHE). A pre-incubation step of $10 \mathrm{~min}$ at $95^{\circ} \mathrm{C}$ was included. cDNA amplification was carried out in 45 cycles under the following conditions: denaturation for $10 \mathrm{~s}$ at $95^{\circ} \mathrm{C}$, annealing for $10 \mathrm{~s}$ at $60^{\circ} \mathrm{C}$, and elongation for $10 \mathrm{~s}$ at $72^{\circ} \mathrm{C}$, including a final melting gradient up to $97^{\circ} \mathrm{C}$ using a ramp of $4.4^{\circ} \mathrm{C} / \mathrm{s}$ to check primer specificity. Each individual reaction was carried out in triplicate including negative controls, No Template Control (NTC) and NonReverse Transcription Control (NRTC). Results were recorded as normalized ratio values by the LightCycler 96 Software version 1.1 following the Pfaffl method (Pfaffl, 2001). Statistical analyses were carried out using ANOVA after observing an approximately normal distribution with QQ-plots, including a post-hoc Tukey HSD test for multiple comparisons. All analyses were carried out using R-Bioconductor (Gentleman et al., 2004).

\subsection{Histone protein extraction, separation and western blot analysis}

Histone protein isolation was performed as described elsewhere (Ausio and Moore, 1998), adapting the protocol to oyster gill tissues in the present work. Accordingly, gills were homogenized with a Dounce Tissue Grinder in $100 \mathrm{mM} \mathrm{KCl}, 50 \mathrm{mM}$ Tris- $\mathrm{HCl}(\mathrm{pH} 7.5)$, $1 \mathrm{Mm} \mathrm{MgCl}_{2}$, and $0.5 \%$ Triton X-100 buffer containing a protease inhibitor mixture. After homogenization and incubation on ice for $5 \mathrm{~min}$, samples were centrifuged for $10 \mathrm{~min}$ at $12,000 \mathrm{~g}\left(4^{\circ} \mathrm{C}\right)$. The 
resulting pellets were resuspended in $0.6 \mathrm{~N} \mathrm{HCl}$, homogenized and centrifuged again. The $\mathrm{HCl}$ supernatant extracts were precipitated overnight with six volumes of acetone at $-20^{\circ} \mathrm{C}$ and centrifuged for $10 \mathrm{~min}$ at $12,000 \mathrm{~g}\left(4^{\circ} \mathrm{C}\right)$. Acetone pellets were dried using a speedvac concentrator and stored at $-80^{\circ} \mathrm{C}$.

The extracted histone proteins were separated using Sodium Dodecyl-Sulfate PolyAcrylamide Gel Electrophoresis (SDS-PAGE) in ClearPAGE SDS gels 4-20\% (C.B.S. SCIENTIFIC). Gels were stained with $0.2 \%(\mathrm{w} / \mathrm{v})$ Coomassie blue in $25 \%(\mathrm{v} / \mathrm{v}) 2$-propanol, $10 \%(\mathrm{v} / \mathrm{v})$ acetic acid, and destained in 10\% (v/v) 2-propanol, 10\% (v/v) acetic acid. Western-blot analyses were performed using commercial human-specific antibodies, including anti-H2A.X (ABCAM), anti$\gamma$ H2A.X (ROCKLAND), anti-H2A.Z (THERMOFISHER SCIENTIFIC); as well as antibodies raised in-house against mollusc macroH2A and $\mathrm{H} 4$ histones. Gels were electro-transferred to a nitrocellulose membrane (C.B.S. SCIENTIFIC) and processed as described elsewhere (Finn et al., 2008). Membranes were incubated with a secondary goat anti-rabbit antibody (ROCKLAND) whose signal was subsequently detected using enhanced chemiluminescence (Amershan ECL Prime Western Blotting Detection Reagent, GE HEALTHCARE LIFE SCIENCES) and a CCD based imager (ChemiDoc-It TS2 Imager, UVP).

\subsection{Genome-wide DNA methylation analysis}

Genomic DNA was purified from gill tissue as described elsewhere (Fernandez-Tajes et al., 2007), adapting the protocol to Eastern oysters in the present work. DNA methylation was analyzed using a Methylation Sensitive Amplified Polymorphism (MSAP) protocol, adapted from (Reyna-Lopez et al., 1997). This method is based on the differential cleavage reactivity to Cytosine methylation (CCGG sites) between the isoesquizomeric endonucleases HpaII and MspI. Accordingly, while HpaII is sensitive to internal Cytosine methylation (i.e., $5^{\prime}-\mathrm{C}^{\mathrm{m}} \mathrm{CGG}-3^{\prime} / 3^{\prime}-\mathrm{GG}^{\mathrm{m}} \mathrm{CC}-5^{\prime}$ ) or hypermethylation states (i.e., $5^{\prime}-{ }^{m} C^{m} C G G-3^{\prime} / 3^{\prime}-G G^{m} C^{m} C-5^{\prime}$ ), MspI is sensitive to external Cytosine methylation, including hemimethylation states where methylation is located on the external Cytosine of the CCGG pattern but on a single DNA strand (i.e., $5^{\prime}$-m CCGG$\left.3^{\prime} / 3^{\prime}-\mathrm{GGCC}-5^{\prime}\right)$ and hypermethylation states. Thus, by comparing both restriction profiles, MSAP analyses provide a basis for establishing global Cytosine methylation patterns and to perform comparisons among different samples (Diaz-Freije et al., 2014). Briefly, gill genomic DNA samples were separately digested with EcoRI/HpaII and EcoRI/MspI in parallel reactions. The resulting fragments were ligated to EcoRI adapters (5'-CTCGTAGACTGCGTACC3', 3'-AATTGGTACGCAGTCTAC-5') and HpaII/MspI adapters (5'GACGATGAGTCTAGAA-3', 3'-CGTTCTAGACTCATC-5'). Digestionligation reactions were performed simultaneously for $2 \mathrm{~h}$ at $37^{\circ} \mathrm{C}$ in a solution consisting of $10 \mathrm{nM}$ DNA, $4 \mathrm{U}$ of EcoRI (NEB), $1 \mathrm{U}$ of either HpaII (NEB) or MspI (NEB), $1 \mathrm{U}$ T4 DNA ligase (NEB), 1X ligase buffer (NEB), 1X CutSmart Buffer (NEB). Restriction fragments were selectively amplified through two consecutive PCR reactions as follows: a first reaction containing $1 \mu \mathrm{L}$ of $1 / 10$ diluted restriction-ligation product, $20 \mathrm{pM}$ of each HpaII/MspI + T (5'-GATGAGTCTAGAACGGT-3') and EcoRI + A (5'GACTGCGTACCAATTCA- $3^{\prime}$ ) primers, $1 \mathrm{X}$ PCR buffer, $0.5 \mathrm{mM}$ dNTPs (THERMO FISHER SCIENTIFIC), $2.5 \mathrm{mM} \mathrm{MgCl}_{2}$, and $1 \mathrm{U}$ BIOTAQ DNA polymerase (BIOLINE). The PCR conditions included an initial denaturation step of $2 \mathrm{~min}$ at $95^{\circ} \mathrm{C}$ followed by 20 amplification cycles $\left(20 \mathrm{~s}\right.$ at $95^{\circ} \mathrm{C} ; 30 \mathrm{~s}$ at $56^{\circ} \mathrm{C} ; 2$ min at $72^{\circ} \mathrm{C}$ ) and a final extension step of $30 \mathrm{~min}$ at $72^{\circ} \mathrm{C}$. The second reaction used $0.5 \mu \mathrm{L}$ of $1 / 10$ of the pre-selective PCR product, $0.83 \mathrm{pM}$ of each 6-FAM labelled selective primer, HpaII/MspI + TAG (5'-GATGAGTCTAGAACGGTCC$\left.3^{\prime}\right)$ and HpaII/MspI + TCC (5'-GATGAGTCTAGAACGGTAG-3'), 1X PCR buffer, $0.5 \mathrm{mM}$ dNTPs, $2.5 \mathrm{mM} \mathrm{MgCl}_{2}$ and $1 \mathrm{U}$ DNA polymerase (BIO$\mathrm{TAQ}$ ). Conditions included an initial denaturation step of $2 \mathrm{~min}$ at $95^{\circ} \mathrm{C}$ followed by 10 amplification cycles $\left(20 \mathrm{~s}\right.$ at $95^{\circ} \mathrm{C}$; $30 \mathrm{~s}$ at $66^{\circ} \mathrm{C} ; 2$ min at $72^{\circ} \mathrm{C}$ ) and a final extension step of 30 min at $72^{\circ} \mathrm{C}$. Amplified products were run in a ABI Prism 310 Genetic Analyzer (APPLIED BIOSYSTEMS) with a GeneScan 500 ROX in the DNA Core facility at Florida International University.

MSAP restriction profiles were scored using the GeneMapper v.3.7 software (APPLIED BIOSYSTEMS) and the resulting absence-presence matrix was analyzed using the $\mathrm{R}$ package MSAP (Perez-Figueroa, 2013). For that purpose, the presence of both EcoRI-HpaII and EcoRI-MspI fragments (1/1) is used as an indicator of unmethylated states; Hemimethylated and internal Cytosine methylated loci are represented by EcoRI-HpaII (1/0) and EcoRI-MspI (0/1) fragments, respectively. Lastly, the absence of both fragments $(0 / 0)$ mirrors either a target mutation (i.e., recognition site CCGG is not present any more) or hypermethylation, being therefore considered uninformative. Differences among methylation profiles were studied throughout the experiment using Analysis of MOlecular VAriance (AMOVA) and Principal Component Analysis (PCA). Statistical significance was assessed using Fisher's exact tests

(Benjamini \& Hochberg multi-test corrections, adjusted $p<0.05$ ) based on counts for the four pattern categories (unmethylated, hemimethylated, hypermethylated, and internal Cytosine methylation), identifying loci with non-random distribution of methylation states. Relationship estimates were computed using Gower's Coefficient of Similarity, and the resulting distance matrix was clustered using UPGMA and visualized as a heatmap with the “ComplexHeatmap” R package (Gu et al., 2016).

\section{Results and discussion}

\subsection{Florida Red Tide simulation and feeding response in Eastern oysters}

FRTs are usually patchy and highly mobile (i.e., driven by currents and wind), displaying heterogeneous dinoflagellate concentrations as these episodes develop (Carvalho et al., 2011). In order to improve HAB simulation, the present work focused on the first $24 \mathrm{~h}$ of a FRT episode, where dinoflagellate concentrations can be predicted more accurately. Accordingly, Eastern oyster individuals were exposed to an exponential increase in the concentration of the brevetoxin-producing dinoflagellate $K$. brevis (Fig. 1A), simulating a typical medium-high intensity FRT episode (Stumpf et al., 2003). The presence of active feeding in exposed oysters was corroborated by the reduction in the number of $K$. brevis cells in experimental tanks after each hourly dosage application (Fig. 1B), as well as by additional indicators including oyster valve opening and production of feces. These results, together with the absence of oyster mortality and the stability in water quality parameters throughout the experiment and across treatment groups, support the effectiveness of $\mathrm{HAB}$ simulation in ensuring exposure of Eastern oysters to brevetoxins through $K$. brevis ingestion.

\subsection{Eastern oyster exposure to K. brevis does not trigger specific modifications in the expression of H2A.X, H2A.Z and macroH2A}

Different epigenetic mechanisms participate in environmental responses, including histone variants encompassing highly specialized functions (Talbert and Henikoff, 2014). Among the different histone families constituting the nucleosome, H2A and H3 display the highest diversity of variants, including H2A.X, H2A.Z, macroH2A, and H2A.Bbd (H2A family); as well as H3.3 and cenH3 (H3 family), among several others [see (Cheema and Ausio, 2015; Henikoff and Smith, 2015) for additional details]. Among H2A variants, H2A.X, H2A.Z and macroH2A stand out due 
A

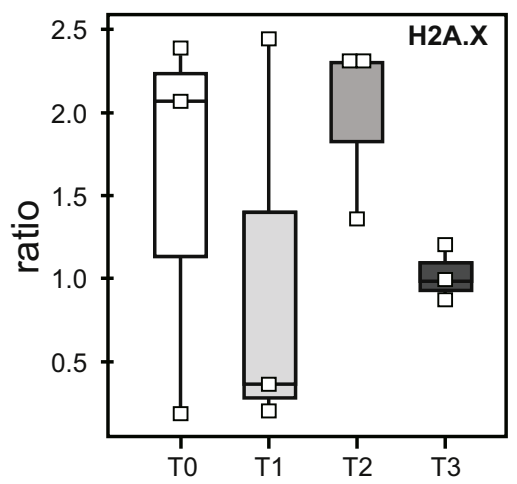

B

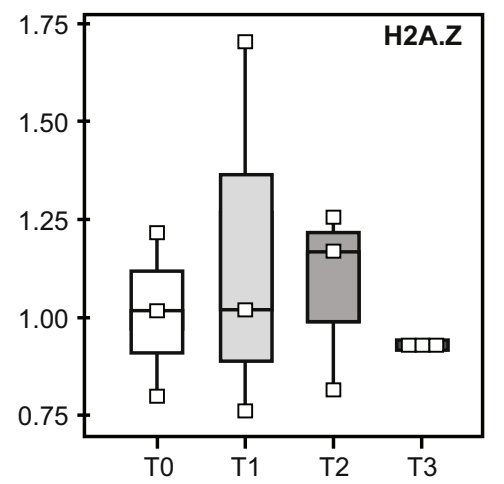

C

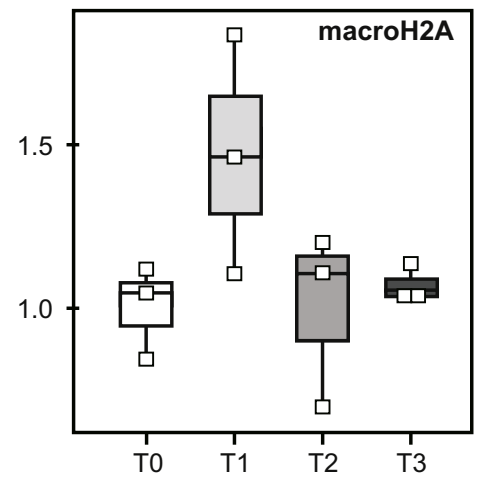

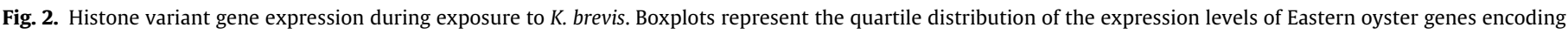

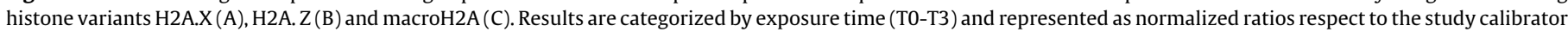
(i.e., gene expression at T0). Boxes and whiskers show a large dispersion in the data for each group of samples, and no significant differences between groups.

Table 2

Frequency (\%) of different methylation states at target sequences across different time points.

\begin{tabular}{|c|c|c|c|c|c|}
\hline \multirow[t]{2}{*}{ Band pattern } & \multirow[t]{2}{*}{ Methylation state } & \multicolumn{4}{|c|}{ Time points } \\
\hline & & T0 & $\mathrm{T} 1$ & $\mathrm{~T} 2$ & T3 \\
\hline $\mathrm{HPA}+/ \mathrm{MSP}+$ & Unmethylated & 0.1017 & 0.1085 & 0.2017 & 0.1856 \\
\hline $\mathrm{HPA}+/ \mathrm{MSP}-$ & Hemimethylated & 0.0958 & 0.0991 & 0.1576 & 0.1763 \\
\hline HPA-/MSP+ & Internal Cytosine methylation & 0.1059 & 0.1525 & 0.0898 & 0.1398 \\
\hline HPA-/MSP- & Full methylation or absence of target & 0.6966 & 0.6398 & 0.5508 & 0.4983 \\
\hline
\end{tabular}

to their involvement (along with PTMs) in the maintenance of genome integrity (Li et al., 2005; Ivashkevich et al., 2012; Shi and Oberdoerffer, 2012; Papamichos-Chronakis and Peterson, 2013; Khurana et al., 2014). Given the ability of brevetoxins to induce DNA damage (Radwan and Ramsdell, 2008; Murrell and Gibson, 2009, 2011), it is hypothesized here that genes encoding H2A.X, H2A.Z and macroH2A will be differentially regulated in response to these stressors. Consequently, the expression of these variants was analyzed during $\mathrm{HAB}$ simulation, constituting the first report describing their presence in oysters. The obtained results revealed an absence of significant changes in gene expression across different time points (adjusted $p$-value $>0.05$ ) and a substantial amount of inter-individual variation (Fig. 2). That is best exemplified by the expression of H2A.X at time point T1 (Fig. 2A), where individuals under similar experimental conditions display a two-fold factor difference in gene expression. These results suggest that oyster responses to $K$. brevis exposure do not involve specific modifications in H2A.X, H2A.Z and macroH2A transcription. Yet, it still might be possible that specific cause-effect relationships are masked by the high levels of variation observed.

The role of histone variants was further investigated by studying H2A.X, H2A.Z and macroH2A protein expression levels (Fig. 3). This work is the first report describing the presence of these proteins in oysters, as well as the validity of commercial antibodies to detect histone variants in this group. Two of these antibodies constitute commercial products specifically raised against human H2A.X and H2A.Z histones. Their suitability for the study of oyster variants is supported by the high level of evolutionary conservation displayed by these proteins in eukaryotes (Malik and Henikoff, 2003; Eirín-López et al., 2009), as well as by previous reports supporting the experimental application of these antibodies in molluscs (González-Romero et al., 2012; Rivera-Casas et al., 2016b). In the case of macroH2A, an antibody specifically raised against mussel macroH2A (able to specifically detect this variant in invertebrates) was used, further supporting its suitability for oysters (Rivera-Casas et al., 2016a). Similarly to gene expression analyses, western blot hybridizations did not show substantial modifications in H2A.X, H2A.Z or macroH2A protein levels throughout HAB simulation (Fig. 3B). Altogether, these results suggest that oyster exposure to FRTs does not result in specific transcriptional or translational modifications in the studied histone variants. Nonetheless, an active role for histone variants during environmental responses, without invoking modifications in their expression levels, could still be possible. Accordingly, the dynamic mobilization of pre-existing histone variants to specific chromatin regions was described during environmental responses (Morrison and Shen, 2005; Weber and Henikoff, 2014), including responses to DNA damage (Lopez et al., 2012). Long-term exposure simulations combined with biopsy sampling of specific individuals (Acosta-Salmón and Southgate, 2004) will complement the present results, helping ascertain the nature of the role played by histone variants during environmental responses (Romero-Geraldo et al., 2014, 2016).

\section{3. $\gamma H 2 A . X$ increases in oysters exposed to growing concentrations of $\mathrm{K}$. brevis}

The phosphorylation of a Serine residue at the C-terminal domain of the H2A.X protein ( $\gamma$ H2A.X) and its subsequent accumulation at damaged chromatin regions ( $\gamma \mathrm{H} 2 \mathrm{~A} . \mathrm{X}$ foci) rapidly marks double-stranded DNA breaks for repair, constituting a biomarker of DNA damage widely used in standardized assays (Kuo and Yang, 2008; Turinetto and Giachino, 2015). Since DNA breaks stand out as the most severe effects caused by brevetoxin exposure (Altaf et al., 2007; Radwan and Ramsdell, 2008; Murrell and Gibson, 2009, 2011), protein expression analyses were complemented with the study of $\gamma \mathrm{H} 2 \mathrm{~A} . \mathrm{X}$ dynamics during HAB simulation. The obtained results revealed an increase in $\gamma H 2 A . X$, concomitantly with the exposure of Eastern oysters to increasing concentrations of $K$. brevis $(\mathrm{T} 1, \mathrm{~T} 2)$, and followed by a slight decrease during the recovery phase (T3, Fig. 3C). Based on these results, it seems plausible that $\gamma$ H2A.X formation is triggered by the genotoxic effect of brevetoxins on Eastern oysters (Li et al., 2005; Ivashkevich et al., 2012). This find- 


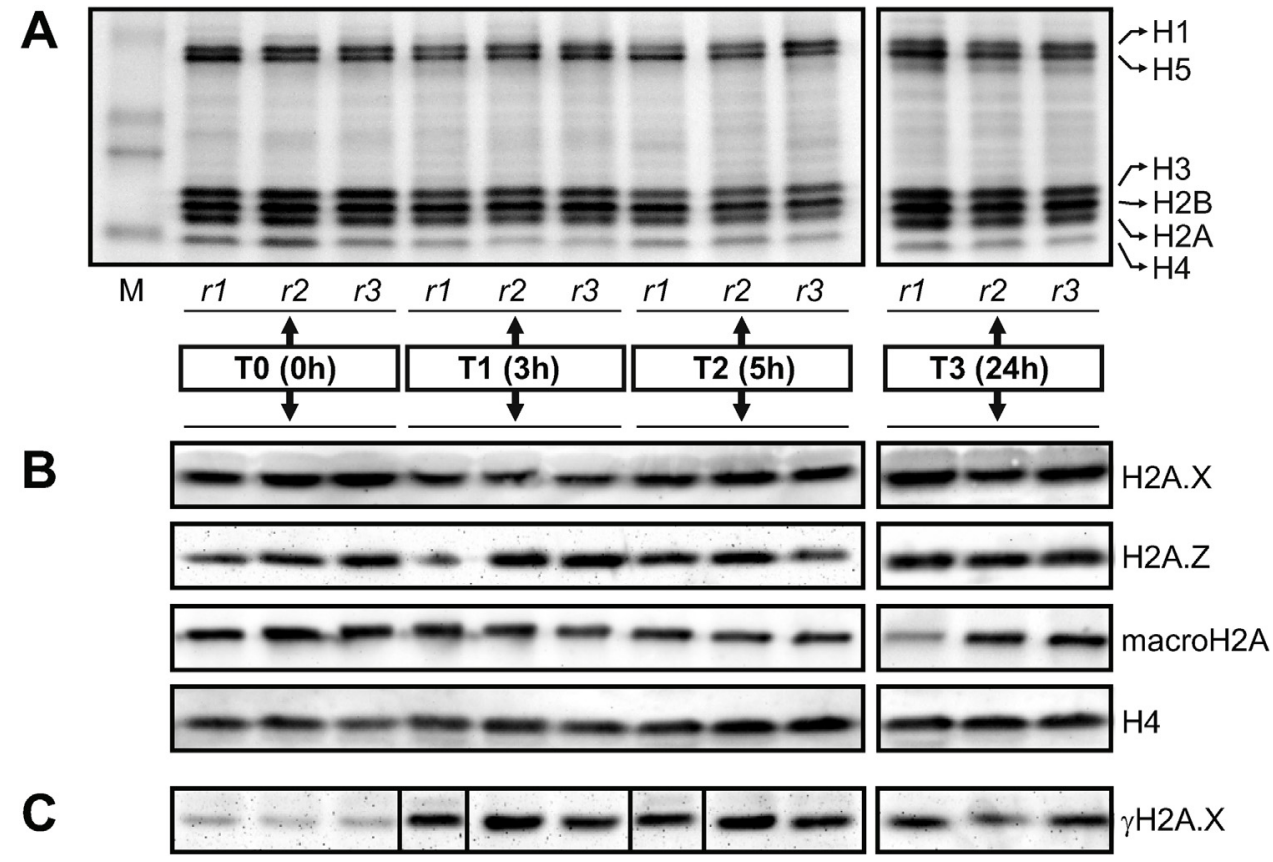

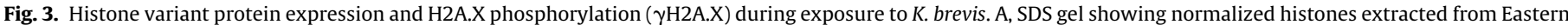

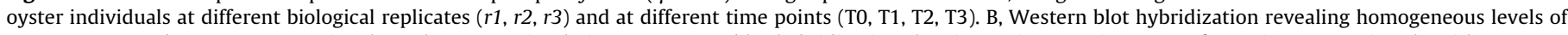

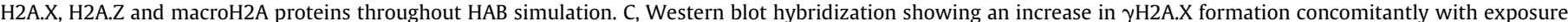

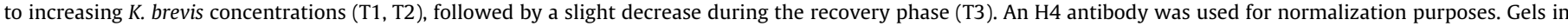
different boxes denote independent hybridization experiments. M, ClearPAGE Two-Color Marker (C.B.S. SCIENTIFIC).

ing has a dual relevance: first, it corroborates the specialization of histone variants and PTMs in the chromatin of molluscs (GonzálezRomero et al., 2012; Rivera-Casas et al., 2016a,b), supporting a role for $\gamma \mathrm{H} 2 \mathrm{~A}$.X during environmental responses in invertebrates (Suarez-Ulloa et al., 2015) and the evolutionary conservation of this mechanism (Kinner et al., 2008; Lee et al., 2014). Second, it validates the application of commercial antibodies to detect $\gamma \mathrm{H} 2 \mathrm{~A} . \mathrm{X}$ in bivalves, opening new avenues for monitoring DNA damage and health in populations of marine invertebrates.

\subsection{Global DNA methylation decreases in oysters during $H A B$ simulation}

The regulatory role of DNA methylation during environmental responses was previously investigated in marine invertebrates, linking modifications in methylation of stress-responsive genes with phenotypic plasticity and adaptation (Gavery and Roberts, 2010). The present work builds on those results, monitoring DNA methylation in Eastern oysters during HAB simulation. Methylation Sensitive Amplified Polymorphism (MSAP) analyses revealed a total of 428 bands, including 295 methylation-susceptible loci. Among those, 204 (69\%) were considered polymorphic (i.e., they have at least two occurrences of both states). The analysis of different methylation states over time revealed a slight increase in unmethylated and hemimethylated states and a loss of fully methylated bands as HAB simulation progressed (T2 and T3, Table 2). More specifically, comparisons among different time points revealed significant differences in DNA methylation ( $\Phi S T=0.1296, p<0.05$, Table 3), notably between earlier (T0, T1) and later (T2, T3) exposure, as well as between T2 and T3. Such differences were further evidenced by Principal Component Analysis (PCA), comparing samples in a space of reduced dimensionality (Fig. 4A). Accordingly, the first coordinate $(\mathrm{C} 1)$ accounts for $16 \%$ of the observed variation in DNA methylation, allowing to discriminate between two major groups: one of them corresponding to the early time points ( $\mathrm{TO}$ and $\mathrm{T} 1$ ), and the other one to the overexposed oyster samples from T2
Table 3

Pairwise AMOVAs between exposure time points based on complete MSAP methylation profiles. ФST values and $p$-values are indicated in the upper and lower diagonal, respectively.

\begin{tabular}{lllll}
\hline & T0 & T1 & T2 & T3 \\
\hline T0 & & -0.0087 & 0.3543 & 0.4131 \\
T1 & 0.6489 & & 0.4188 & 0.4167 \\
T2 & $0.0311^{*}$ & $0.0255^{*}$ & & 0.3333 \\
T3 & $0.0291^{*}$ & $0.0284^{*}$ & $0.0290^{*}$ & \\
\hline${ }^{*} p<0.05$. & & & &
\end{tabular}

and T3. The observed differences in DNA methylation were further supported by Fisher exact tests, identifying 10 MSAP loci showing significant differences $(p<0.05)$ between early (T0 and T1) and late (T2 and T3) exposure times (Fig. 4B). These loci were characterized based on methylation profiles, defining two groups: a first one predominantly showing internal Cytosine methylation at T0 and T1, but mostly unmethylated at T2 and T3 (left cluster); and a second group consisting of fully methylated fragments undergoing demethylation towards later exposure times (right cluster). Overall, MSAP results were consistent with a decrease in genome-wide DNA methylation levels as K. brevis concentration increased.

Specific DNA methylation profiles contribute to environmentally induced phenotypes, displaying different levels of heritability in invertebrates (Vandegehuchte et al., 2009). In the case of molluscs, DNA methylation participates in the epigenetic regulation of gene expression during development (Riviere et al., 2013; DiazFreije et al., 2014), as well as during responses to environmental stress (Gavery and Roberts, 2014). Furthermore, it has been recently suggested that a reduction in global DNA methylation during early invasive episodes could compensate for low genetic variation caused by founder effects in the pygmy mussel (Ardura et al., 2017). Particularly, DNA hypomethylation was described in different organisms during responses to environmental pollution (Vandegehuchte et al., 2009; Chen et al., 2012; Fang et al., 2013; Dimond and Roberts, 2016), including exposure to agents inducing 
A

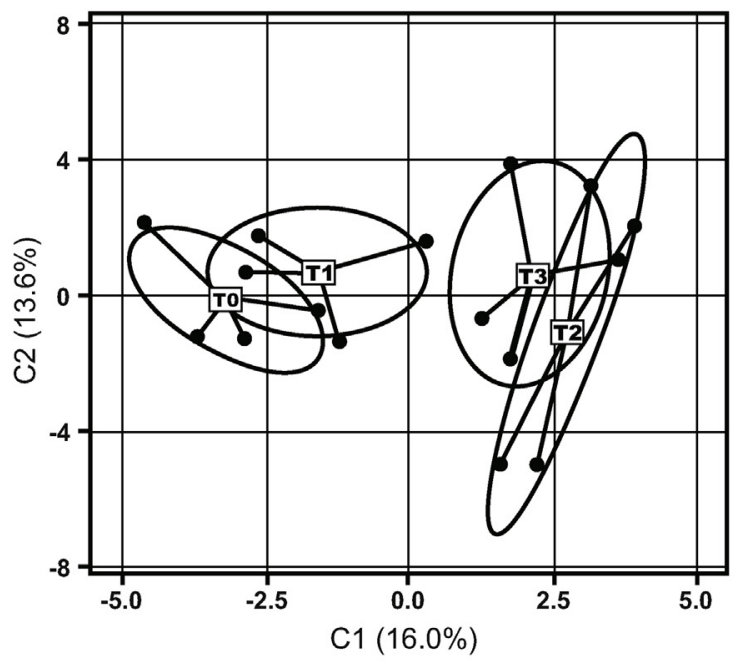

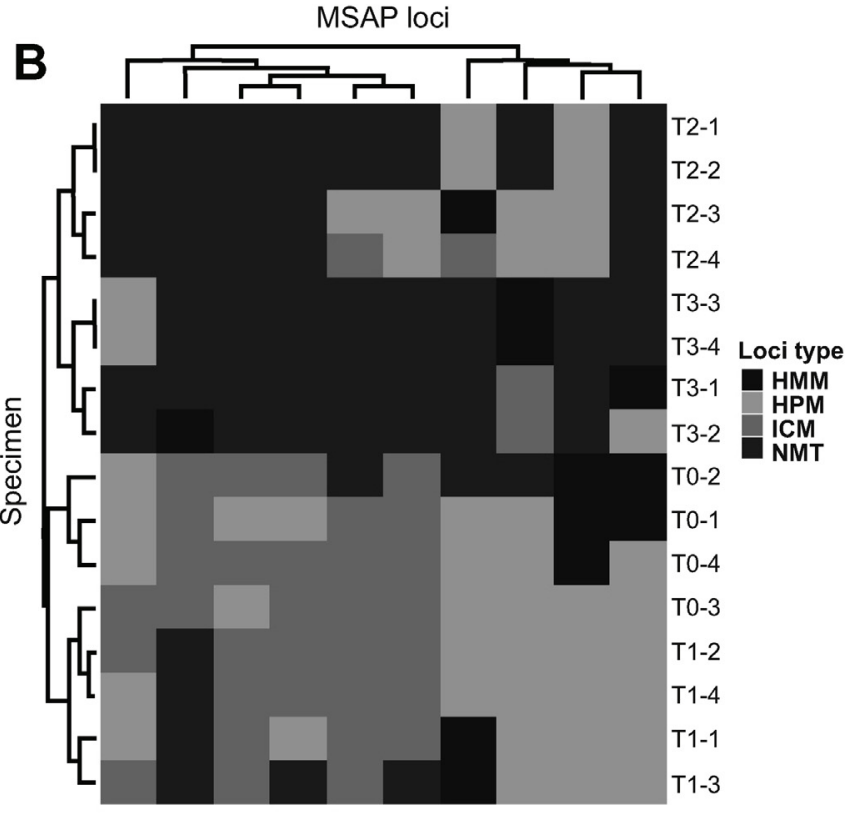

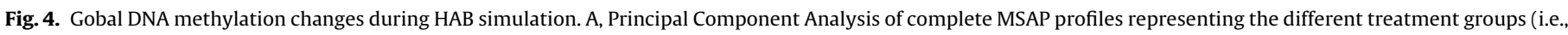

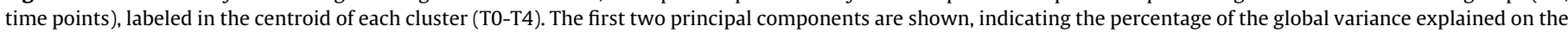

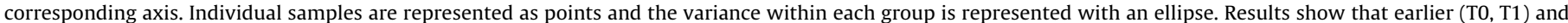

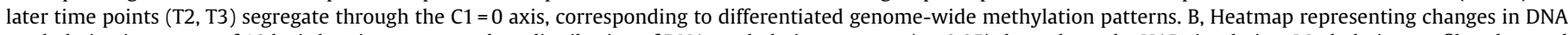

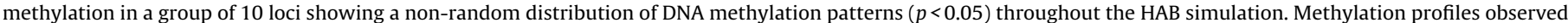

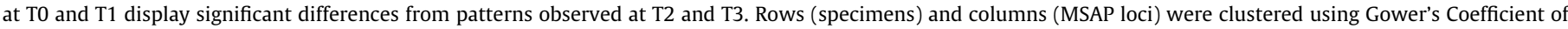

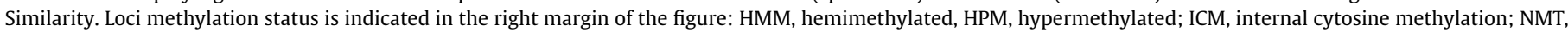
non-methylated (unmethylated).

oxidative stress (Mirbahai and Chipman, 2014). Given the ability of brevetoxins to induce oxidative damage, it seems plausible that the observed reduction in global DNA methylation in Eastern oysters is a direct consequence of their exposure to the brevetoxin-producing K. brevis during $\mathrm{HAB}$ simulation.

\section{Conclusions}

The present work investigated the effects of FRTs on two types of mechanisms potentially participating in the epigenetic memory of Eastern oysters: histone variants and DNA methylation. This research revealed, for the first time, the existence of H2A.X, H2A.Z and macroH2A genes in oysters along with their active transcription and translation, validating the application of specific qPCR primers, as well as commercial and invertebrate-specific antibodies for their study in vivo. While the expression of these variants does not seem to be specifically altered during FRTs, the observed increase in $\gamma \mathrm{H} 2 \mathrm{~A}$.X would be consistent with the presence of oxidative DNA damage in Eastern oysters, as a consequence of their exposure to brevetoxins produced by $K$. brevis. Based on these results, the application of $\gamma \mathrm{H} 2 \mathrm{~A}$.X as a biomarker of oxidative stress seems plausible, with obvious implications for the conservation and management of Eastern oysters as well as other marine invertebrates. Still, further analyses clarifying the relationship between the magnitude of $\gamma \mathrm{H} 2 \mathrm{~A} . \mathrm{X}$ and the levels of DNA damage will be required to fully elucidate the applicability of this histone variant modification in this group of organisms. Additionally, the study of DNA methylation patterns revealed significant differences between early (T0, T1) and late (T2, T3) stages of the HAB simulation. More precisely, a decrease in genome-wide DNA methylation levels was observed as the simulation progressed. These results are consistent with the documented connection between DNA hypomethylation and environmental responses (Vandegehuchte et al., 2010; Chen et al., 2012; Fang et al., 2013; Dimond and Roberts 2016), thus supporting an active role for this epigenetic mechanism during oyster responses to $K$. brevis exposure (i.e., modulation of genes specifically involved in responses to brevetoxin stress). Overall, the present work provides a basis to better understand how epigenetic mechanisms participate in responses to environmental stress in marine invertebrates. By doing so, it opens new avenues to incorporate environmental epigenetics approaches into management and conservation programs.

\section{Acknowledgments}

This work was supported by grants from the Biomolecular Sciences Institute (800005997) the College of Arts, Sciences and Education (CASE) at Florida International University (JME-L). This material is based upon work supported in part by the National Science Foundation under Grant No. HRD-1547798. This NSF Grant was awarded to Florida International University as part of the Centers for Research Excellence in Science and Technology (CREST) Program. VS-U was supported by a Dissertation Year Fellowship (DYF) awarded by the University Graduate School (UGS) at Florida International University. This is contribution \#25 from the Marine Education and Research Center in the Institute for Water and Environment at Florida International University. Thanks are also due to Rookery Bay National Estuarine Research Reserve for providing access to Eastern oyster specimens and to Kathleen Rein for providing the $K$. brevis culture used in HAB simulations.

\section{References}

Abraham, W.M., Bourdelais, A.J., Sabater, J.R., Ahmed, A., Lee, T.A., Serebriakov, I., Baden, D.G., 2005. Airway responses to aerosolized brevetoxins in an animal model of asthma. Am. J. Respir. Crit. Care Med. 171, 26-34.

Acosta-Salmón, H., Southgate, P.C., 2004. Use of a biopsy technique to obtain gonad tissue from the blacklip pearl oyster Pinctada margaritifera (L.). Aquacult. Res. 35, 93-96. 
Allis, C.D., Jenuwein, T., Reinberg, D., 2007. Epigenetics. Cold Spring Harbor Laboratory Press, New York.

Altaf, M., Saksouk, N., Cote, J., 2007. Histone modifications in response to DNA damage. Mutat. Res. 618, 81-90.

Ardura, A., Zaiko, A., Moran, P., Planes, S., Garcia-Vazquez, E., 2017. Epigenetic signatures of invasive status in populations of marine invertebrates. Sci. Rep. 7 , 42193

Arenas-Mena, C., Wong, K.S., Arandi-Foroshani, N.R., 2007. Histone H2A.Z expression in two indirectly developing marine invertebrates correlates with undifferentiated and multipotent cells. Evol. Dev. 9, 231-243.

Arya, G., Maitra, A., Grigoryev, S.A., 2010. A structural perspective on the where, how, why, and what of nucleosome positioning. J. Biomol. Struct. Dyn. 27, 803-820.

Ausio, J., Moore, S.C., 1998. Reconstitution of chromatin complexes from high-performance liquid chromatography-purified histones. Methods 15, 333-342.

Baccarelli, A., Bollati, V., 2009. Epigenetics and environmental chemicals. Curr. Opin. Pediatr. 21, 243-251.

Bollati, V., Baccarelli, A., 2010. Environmental epigenetics. Heredity 105, 105-112

Brand, L.E., Compton, A., 2007. Long-term increase in Karenia brevis abundance along the Southwest Florida Coast. Harmful Algae 6, 232-252.

Brand, L.E., Campbell, L., Bresnan, E., 2012. Karenia: the biology and ecology of a toxic genus. Harmful Algae 14, 156-178.

Campos, A., Tedesco, S., Vasconcelos, V., Cristobal, S., 2012. Proteomic research in bivalves: towards the identification of molecular markers of aquatic pollution. J. Proteom. 75, 4346-4359.

Cardozo, K.H., Guaratini, T., Barros, M.P., Falcao, V.R., Tonon, A.P., Lopes, N.P., Campos, S., Torres, M.A., Souza, A.O., Colepicolo, P., Pinto, E., 2007. Metabolites from algae with economical impact. Comp. Biochem. Physiol. C Toxicol. Pharmacol. 146, 60-78

Carvalho, G.A., Minnett, P.J., Banzon, V.F., Baringer, W., Heil, C.A., 2011. Long-term evaluation of three satellite ocean color algorithms for identifying harmfu algal blooms (Karenia brevis) along the west coast of Florida: a matchup assessment. Remote Sens. Environ. 115, 1-18.

Cheema, M.S., Ausio, J., 2015. The structural determinants behind the epigenetic role of histone variants. Genes (Basel) 6, 685-713.

Chen, T., Williams, T.D., Mally, A., Hamberger, C., Mirbahai, L., Hickling, K., Chipman, J.K., 2012. Gene expression and epigenetic changes by furan in rat liver. Toxicology 292, 63-70.

Collin, H., Meistertzheim, A.L., David, E., Moraga, D., Boutet, I., 2010. Response of the Pacific oyster Crassostrea gigas, Thunberg 1793, to pesticide exposure under experimental conditions. J. Exp. Biol. 213, 4010-4017.

Cook, P.F., Reichmuth, C., Rouse, A.A., Libby, L.A., Dennison, S.E., Carmichael, O.T., Kruse-Elliott, K.T., Bloom, J., Singh, B., Fravel, V.A., Barbosa, L., Stuppino, J.J., Van Bonn, W.G., Gulland, F.M.D., Ranganath, C., 2015. Algal toxin impairs sea lion memory and hippocampal connectivity, with implications for strandings. Science 350, 1545-1547.

Cortessis, V.K., Thomas, D.C., Levine, A.J., Breton, C.V., Mack, T.M., Siegmund, K.D., Haile, R.W., Laird, P.W., 2012. Environmental epigenetics: prospects for studying epigenetic mediation of exposure-response relationships. Hum. Genet. 131, 1565-1589.

Curry, R., Mauritzen, C., 2005. Dilution of the northern North Atlantic Ocean in recent decades. Science 308, 1772-1774.

Dame, R.F., 1972. The ecological energies of growth, respiration, and assimilation in the intertidal American oyster Crassostrea virginica. Mar. Biol. 17, 243-250.

Davis, C., 1948. Gymnodinium breve: a cause of discolored water and animal mortality in the Gulf of Mexico. Bot. Gaz. 109, 358-360.

Diaz-Freije, E., Gestal, C., Castellanos-Martinez, S., Moran, P., 2014. The role of DNA methylation on Octopus vulgaris development and their perspectives. Front. Physiol. 5.

Dimond, J.L., Roberts, S.B., 2016. Germline DNA methylation in reef corals: patterns and potential roles in response to environmental change. Mol. Ecol. 25, 1895-1904.

Eirín-López, J.M., González-Romero, R., Dryhurst, D., Méndez, J., Ausió, J., 2009. Long-term evolution of histone families: old notions and new insights into their diversification mechanisms across eukaryotes. In: Pontarotti, P. (Ed.) Evolutionary Biology: Concept, Modeling, and Application. Springer-Verlag, Berlin, Heidelberg

Errera, R.M., Yvon-Lewis, S., Kessler, J.D., Campbell, L., 2014. Reponses of the dinoflagellate Karenia brevis to climate change: $\mathrm{pCO}_{2}$ and sea surface temperatures. Harmful Algae 37, 110-116.

Etchegaray, J.P., Mostoslavsky, R., 2016. Interplay between metabolism and epigenetics: a nuclear adaptation to environmental changes. Mol. Cell 62 695-711.

Fang, X., Thornton, C., Scheffler, B.E., Willett, K.L., 2013. Benzo[a]pyrene decreases global and gene specific DNA methylation during zebrafish development. Environ. Toxicol. Pharmacol. 36, 40-50.

Feil, R., Fraga, M.F., 2012. Epigenetics and the environment: emerging patterns and implications. Nat. Rev. Genet. 13, 97-109.

Fernandez, A.F., Torano, E.G., Urdinguio, R.G., Lana, A.G., Fernandez, I.A., Fraga, M.F., 2014. The epigenetic basis of adaptation and responses to environmental change: perspective on human reproduction. Adv. Exp. Med. Biol. 753, 97-117.

Fernandez-Tajes, J., Gaspar, M., Martinez-Patino, D., McDonough, N., Roberts, D., González-Tizón, A.M., Martinez-Lage, A., Mendez, J., 2007. Genetic variation of the razor clam Ensis siliqua (Jeffreys, 1875) along the European coast based on random amplified polymorphic DNA markers. Aquac. Res. 38, 1205-1212.
Fernandez-Tajes, J., Arias-Perez, A., Fernandez-Moreno, M., Mendez, J., 2012. Sharp decrease of genetic variation in two Spanish localities of razor clam Ensis siliqua: natural fluctuation or prestige oil spill effects? Ecotoxicology 21, 225-233.

Finn, R.M., Browne, K., Hodgson, K.C., Ausio, J., 2008. sNASP, a histone H1-specific eukaryotic chaperone dimer that facilitates chromatin assembly. Biophys. J. 95 1314-1325.

Fleming, L.E., Kirkpatrick, B., Backer, L.C., Bean, J.A., Wanner, A., Reich, A., Zaias, J., Cheng, Y.S., Pierce, R., Naar, J., Abraham, W.M., Baden, D.G., 2007. Aerosolized red-tide toxins (brevetoxins) and asthma. Chest 131, 187-194.

Flewelling, L.J., Naar, J.P., Abbott, J.P., Baden, D.G., Barros, N.B., Bossart, G.D., Bottein, M.Y., Hammond, D.G., Haubold, E.M., Heil, C.A., Henry, M.S., Jacocks, H.M., Leighfield, T.A., Pierce, R.H., Pitchford, T.D., Rommel, S.A., Scott, P.S., Steidinger, K.A., Truby, E.W., Van Dolah, F.M., Landsberg, J.H., 2005. Brevetoxicosis: red tides and marine mammal mortalities. Nature 435, 755-756.

Gavery, M.R., Roberts, S.B., 2010. DNA methylation patterns provide insight into epigenetic regulation in the Pacific oyster (Crassostrea gigas). BMC Genomics $11,483$.

Gavery, M.R., Roberts, S.B., 2013. Predominant intragenic methylation is associated with gene expression characteristics in a bivalve mollusc. Peer J. 1, e215.

Gavery, M.R., Roberts, S.B., 2014. A context dependent role for DNA methylation in bivalves. Brief. Funct. Genomics 13, 217-222.

Gentleman, R.C., Carey, V.J., Bates, D.M., Bolstad, B., Dettling, M., Dudoit, S., Ellis, B., Gautier, L., Ge, Y., Gentry, J., Hornik, K., Hothorn, T., Huber, W., Iacus, S., Irizarry, R., Leisch, F., Li, C., Maechler, M., Rossini, A.J., Sawitzki, G., Smith, C., Smyth, G., Tierney, L., Yang, J.Y., Zhang, J., 2004. Bioconductor: open software development for computational biology and bioinformatics. Genome Biol. 5, R80.

González-Romero, R., Rivera-Casas, C., Frehlick, L.J., Méndez, J., Ausió, J., Eirín-López, J.M., 2012. Histone H2A (H2A.X. and H2A.Z) variants in molluscs: molecular characterization and potential implications for chromatin dynamics. PLoS One 7, e30006.

Gu, Z., Eils, R., Schlesner, M., 2016. Complex heatmaps reveal patterns and correlations in multidimensional genomic data. Bioinformatics 32, 2847-2849.

Henikoff, S., Smith, M.M., 2015. Histone variants and epigenetics. Cold Spring Harb. Perspect. Biol. 7, a019364.

Hoffmann, A.A., Willi, Y., 2008. Detecting genetic responses to environmental change. Nat. Rev. Genet. 9, 421-432.

Ivashkevich, A., Redon, C.E., Nakamura, A.J., Martin, R.F., Martin, O.A., 2012. Use of the gamma-H2AX assay to monitor DNA damage and repair in translational cancer research. Cancer Lett. 327, 123-133.

Khurana, S., Kruhlak, M.J., Kim, J., Tran, A.D., Liu, J., Nyswaner, K., Shi, L., Jailwala, P., Sung, M.H., Hakim, O., Oberdoerffer, P., 2014. A macrohistone variant links dynamic chromatin compaction to BRCA1-dependent genome maintenance. Cell Rep. 8, 1049-1062.

Kinner, A., Wu, W., Staudt, C. Iliakis, G., 2008. Gamma-H2AX in recognition and signaling of DNA double-strand breaks in the context of chromatin. Nucleic Acids Res. 36, 5678-5694.

Kouzarides, T., 2007. Chromatin modifications and their function. Cell 128, 693-705.

Kuo, L.J., Yang, L.X., 2008. Gamma-H2AX-a novel biomarker for DNA double-strand breaks. In Vivo 22, 305-309.

Lee, C.S., Lee, K., Legube, G., Haber, J.E., 2014. Dynamics of yeast histone H2A and H2 B phosphorylation in response to a double-strand break. Nat. Struct. Mol. Biol. 21, 103-109.

Leverone, J.R., Blake, N.J., Pierce, R.H., Shumway, S.E., 2006. Effects of the dinoflagellate Karenia brevis on larval development in three species of bivalve mollusc from Florida. Toxicon 48, 75-84.

Li, A., Eirín-López, J.M., Ausió, J., 2005. H2AX: tailoring histone H2A for chromatin-dependent genomic integrity. Biochem. Cell Biol. 83, 505-515.

Lopez, M.F., Tollervey, J., Krastins, B., Garces, A., Sarracino, D., Prakash, A., Vogelsang, M., Geesman, G., Valderrama, A., Jordan, I.K., Lunyak, V.V., 2012 Depletion of nuclear histone H2A variants is associated with chronic DNA damage signaling upon drug-evoked senescence of human somatic cells. Aging (Albany NY) 4, 823-842.

Luchmann, K.H., Mattos, J.J., Siebert, M.N., Dorrington, T.S., Toledo-Silva, G., Stoco, P.H., Grisard, E.C., Bainy, A.C., 2012. Suppressive subtractive hybridization libraries prepared from the digestive gland of the oyster Crassostrea brasiliana exposed to a diesel fuel water-accommodated fraction. Environ. Toxicol. Chem. $31,1249-1253$

Malik, H.S., Henikoff, S., 2003. Phylogenomics of the nucleosome. Nat. Struct. Biol. $10,882-891$.

Mat, A.M., Haberkorn, H., Bourdineaud, J.P., Massabuau, J.C., Tran, D., 2013. Genetic and genotoxic impacts in the oyster Crassostrea gigas exposed to the harmful alga Alexandrium minutum. Aquat. Toxicol. 140-141, 458-465.

McFarren, E.F., Silva, F.J., Tanabe, H., Wilson, W.B., Campbell, J.E., Lewis, K.H., 1965. The occurrence of a ciguatera-like poison in oysters, clams, and Gymnodinium breve cultures. Toxicon 3,111-123.

Mello, D.F., de Oliveira, E.S., Vieira, R.C., Simoes, E., Trevisan, R., Dafre, A.L., Barracco, M.A., 2012. Cellular and transcriptional responses of Crassostrea gigas hemocytes exposed in vitro to brevetoxin (PbTx-2). Mar Drugs 10, 583-597.

Mercer, T.R., Mattick, J.S., 2013. Structure and function of long noncoding RNAs in epigenetic regulation. Nat. Struct. Mol. Biol. 20, 300-307.

Migicovsky, Z., Kovalchuk, I., 2011. Epigenetic memory in mammals. Front. Genet. 2,28 . 
Milan, M., Pauletto, M., Patarnello, T., Bargelloni, L., Marin, M.G., Matozzo, V., 2013. Gene transcription and biomarker responses in the clam Ruditapes philippinarum after exposure to ibuprofen. Aquat. Toxicol. 126, 17-29.

Mirbahai, L., Chipman, J.K., 2014. Epigenetic memory of environmental organisms: a reflection of lifetime stressor exposures. Mutat. Res. Genet. Toxicol. Environ. Mutagen. 764-765, 10-17.

Morrison, A.J., Shen, X., 2005. DNA repair in the context of chromatin. ABBV Cell Cycle 4, 568-571.

Murrell, R.N., Gibson, J.E., 2009. Brevetoxins 2, 3, 6, and 9 show variability in potency and cause significant induction of DNA damage and apoptosis in Jurkat E6-1 cells. Arch. Toxicol. 83, 1009-1019.

Murrell, R.N., Gibson, J.E., 2011. Brevetoxin 2 alters expression of apoptotic, DNA damage, and cytokine genes in Jurkat cells. Hum. Exp. Toxicol. 30, 182-191.

Olson, C.E., Roberts, S.B., 2014. Genome-wide profiling of DNA methylation and gene expression in Crassostrea gigas male gametes. Front. Physiol. 5, 224.

Papamichos-Chronakis, M., Peterson, C.L., 2013. Chromatin and the genome integrity network. Nat. Rev. Genet. 14, 62-75.

Perez-Figueroa, A., 2013. msap: a tool for the statistical analysis of methylation-sensitive amplified polymorphism data. Mol. Ecol. Resour. 13, 522-527.

Perrault, J.R., Schmid, J.R., Walsh, C.J., Yordy, J.E., Tucker, A.D., 2014. Brevetoxin exposure, superoxide dismutase activity and plasma protein electrophoretic profiles in wild-caught Kemp's ridley sea turtles (Lepidochelys kempii) in southwest Florida. Harmful Algae 37, 194-202.

Pfaffl, M.W., 2001. A new mathematical model for relative quantification in real-time RT-PCR. Nucleic Acids Res. 29, e45.

Plakas, S.M., El Said, K.R., Jester, E.L., Granade, H.R., Musser, S.M., Dickey, R.W., 2002. Confirmation of brevetoxin metabolism in the Eastern oyster (Crassostrea virginica) by controlled exposures to pure toxins and to Karenia brevis cultures. Toxicon 40, 721-729.

Plakas, S.M., Jester, E.L., El Said, K.R., Granade, H.R., Abraham, A., Dickey, R.W., Scott, P.S., Flewelling, L.J., Henry, M., Blum, P., Pierce, R., 2008. Monitoring of brevetoxins in the Karenia brevis bloom-exposed Eastern oyster (Crassostrea virginica). Toxicon 52, 32-38

Prego-Faraldo, M.V., Valdiglesias, V., Laffon, B., Eirin-Lopez, J.M., Mendez, J., 2015. In vitro analysis of early genotoxic and cytotoxic effects of okadaic acid in different cell types of the mussel Mytilus galloprovincialis. J. Toxicol. Environ. Health A 78, 814-824.

Prego-Faraldo, M.V., Valdiglesias, V., Laffon, B., Mendez, J., Eirin-Lopez, J.M., 2016. Early genotoxic and cytotoxic effects of the toxic dinoflagellate prorocentrum lima in the mussel Mytilus galloprovincialis. Toxins (Basel) 8, 1-14.

Ptashne, M., 2007. On the use of the word 'epigenetic'. Curr. Biol. 17, R233-236.

Radwan, F.F., Ramsdell, J.S., 2008. Brevetoxin forms covalent DNA adducts in rat lung following intratracheal exposure. Environ. Health Perspect. 116, 930-936.

Reyna-Lopez, G.E., Simpson, J., Ruiz-Herrera, J., 1997. Differences in DNA methylation patterns are detectable during the dimorphic transition of fungi by amplification of restriction polymorphisms. Mol. Gen. Genet. 253, 703-710.

Rivera-Casas, C., Gonzalez-Romero, R., Cheema, M.S., Ausio, J., Eirin-Lopez, J.M., 2016a. The characterization of macroH2A beyond vertebrates supports an ancestral origin and conserved role for histone variants in chromatin. Epigenetics 11, 415-425.

Rivera-Casas, C., Gonzalez-Romero, R., Vizoso-Vazquez, A., Cheema, M.S., Cerdan, M.E., Mendez, J., Ausio, J., Eirin-Lopez, J.M., 2016b. Characterization of musse H2A.Z.2: a new H2A.Z. variant preferentially expressed in germinal tissues from Mytilus. Biochem. Cell Biol. 94, 480-490.

Riviere, G., Wu, G.C., Fellous, A., Goux, D., Sourdaine, P., Favrel, P., 2013. DNA methylation is crucial for the early development in the Oyster $C$. gigas. Mar. Biotechnol. (N. Y.) 15, 739-753.

Rolton, A., Vignier, J., Soudant, P., Shumway, S.E., Bricelj, V.M., Volety, A.K., 2014 Effects of the red tide dinoflagellate, Karenia brevis, on early development of the eastern oyster Crassostrea virginica and northern quahog Mercenaria mercenaria. Aquat. Toxicol. 155, 199-206.

Romero-Geraldo, R.D., Garcia-Lagunas, J.N., Hernandez-Saavedra, N.Y., 2014. Effects of in vitro exposure to diarrheic toxin producer Prorocentrum lima on gene expressions related to cell cycle regulation and immune response in Crassostrea gigas. PLoS One, 9.
Romero-Geraldo, R., Garcia-Lagunas, N., Hernandez-Saavedra, N.Y., 2016 Crassostrea gigas exposure to the dinoflagellate Prorocentrum lima: histological and gene expression effects on the digestive gland. Mar. Environ. Res. 120, 93-102.

Ross, C., Ritson-Williams, R., Pierce, R., Bullington, J.B., Henry, M., Paul, V.J., 2010. Effects of the Florida red tide dinoflagellate, Karenia brevis, on oxidative stress and metamorphosis of larvae of the coral Porites astreoides. Harmful Algae 9, 173-179.

Schulmeister, A., Schmid, M., Thompson, E.M., 2007. Phosphorylation of the histone H3.3 variant in mitosis and meiosis of the urochordate Oikopleura dioica. Chromosome Res. 15, 189-201.

Shi, L., Oberdoerffer, P., 2012. Chromatin dynamics in DNA double-strand break repair. Biochim. Biophys. Acta 1819, 811-819.

Stumpf, R.P., Culver, M.E., Tester, P.A., Tomlinson, M., Kirkpatrick, G.J., Pederson, B.A., Truby, E., Ransibrahmanakul, V., Soracco, M., 2003. Monitoring Karenia brevis blooms in the Gulf of Mexico using satellite ocean color imagery and other data. Harmful Algae 2, 147-160.

Suarez-Ulloa, V., Fernandez-Tajes, J., Aguiar-Pulido, V., Rivera-Casas, C., Gonzalez-Romero, R., Ausio, J., Mendez, J., Dorado, J., Eirin-Lopez, J.M., 2013. The CHROMEVALOA database: a resource for the evaluation of okadaic acid contamination in the marine environment based on the chromatin-associated transcriptome of the mussel Mytilus galloprovincialis. Mar. Drugs 11, 830-841.

Suarez-Ulloa, V., Gonzalez-Romero, R., Eirin-Lopez, J.M., 2015. Environmental epigenetics: a promising venue for developing next-generation pollution biomonitoring tools in marine invertebrates. Mar. Pollut. Bull. 98, 5-13.

Sun, P., Leeson, C., Zhi, X., Leng, F., Pierce, R.H., Henry, M.S., Rein, K.S., 2016. Characterization of an epoxide hydrolase from the Florida red tide dinoflagellate, Karenia brevis. Phytochemistry 122, 11-21.

Sunda, W.G., Burleson, C., Hardison, D.R., Morey, J.S., Wang, Z., Wolny, J., Corcoran, A.A., Flewelling, L.J., Van Dolah, F.M., 2013. Osmotic stress does not trigger brevetoxin production in the dinoflagellate Karenia brevis. Proc. Natl. Acad. Sci. U. S. A. $110,10223-10228$.

Talbert, P.B., Henikoff, S., 2010. Histone variants-ancient wrap artists of the epigenome. Nat. Rev. Mol. Cell Biol. 11, 264-275.

Talbert, P.B., Henikoff, S., 2014. Environmental responses mediated by histone variants. Trends Cell Biol.

Turinetto, V., Giachino, C., 2015. Multiple facets of histone variant H2AX: a DNA double-strand-break marker with several biological functions. Nucleic Acids Res, 43, 2489-2498.

Twiner, M.J., Bottein Dechraoui, M.Y., Wang, Z., Mikulski, C.M., Henry, M.S., Pierce, R.H., Doucette, G.J., 2007. Extraction and analysis of lipophilic brevetoxins from the red tide dinoflagellate Karenia brevis. Anal. Biochem. 369, 128-135.

Valdiglesias, V., Fernandez-Tajes, J., Mendez, J., Pasaro, E., Laffon, B., 2013. The marine toxin okadaic acid induces alterations in the expression level of cancer-related genes in human neuronal cells. Ecotoxicol. Environ. Saf. 92, 303-311.

Vandegehuchte, M.B., Lemiere, F., Janssen, C.R., 2009. Quantitative DNA-methylation in Daphnia magna and effects of multigeneration $\mathrm{Zn}$ exposure. Comp. Biochem. Physiol. C Toxicol. Pharmacol. 150, 343-348.

Vandegehuchte, M.B., Lemiere, F., Vanhaecke, L., Vanden Berghe, W., Janssen, C.R., 2010. Direct and transgenerational impact on Daphnia magna of chemicals with a known effect on DNA methylation. Comp. Biochem. Physiol. C Toxicol. Pharmacol. 151, 278-285.

Walsh, C.J., Butawan, M., Yordy, J., Ball, R., Flewelling, L., de Wit, M., Bonde, R.K., 2015. Sublethal red tide toxin exposure in free-ranging manatees (Trichechus manatus) affects the immune system through reduced lymphocyte proliferation responses, inflammation, and oxidative stress. Aquat. Toxicol. $161,73-84$.

Weber, C.M., Henikoff, S., 2014. Histone variants: dynamic punctuation in transcription. Genes Dev. 28, 672-682.

Ye, J., Coulouris, G., Zaretskaya, I., Cutcutache, I., Rozen, S., Madden, T.L., 2012. Primer-BLAST: a tool to design target-specific primers for polymerase chain reaction. BMC Bioinf. 13, 134

Zhang, L., Li, L., Zhu, Y., Zhang, G., Guo, X., 2014. Transcriptome analysis reveals a rich gene set related to innate immunity in the Eastern oyster (Crassostrea virginica). Mar. Biotechnol. (N. Y.) 16, 17-33. 